\title{
Trade and Child Labor: A Review of Literature
}

\author{
Bilal Tariq \\ Department of Economics, COMSATS University Islamabad, Vehari Campus
}

\section{Rossazana Ab-Rahim}

Faculty of Economics and Business, Universiti Malaysia Sarawak, Kota Samarahan

\author{
Received: Sep. 11, 2019 Accepted: Dec. 13, 2019 Online published: Jan. 13, 2020 \\ doi:10.5296/jpag.v10i1.15429ＵRL: https://doi.org/10.5296/jpag.v10i1.15429
}

\begin{abstract}
Employed child or working child is known as child labor in literature. The child labor is an important issue for economic analysts, governments and social groups. The awareness of the exploitation of children, in much of the developing world, has brought the issue of child labor to the forefront of debate within governments and social groups. The purpose of this study is to organize the past literature on trade and child labor. Additionally, this paper presents the conceptual and empirical discussion with some recent estimates of the magnitude of the problem. The review of past studies presents the child laborers' effect on an economy as well as the debate on the effectiveness of various policies related to trade and economic growth.
\end{abstract}

JEL Classification Numbers: D1, J2, J4

Keywords: child labor, trade openness, comparative advantage

\section{Introduction}

Child labor is considered one of the oldest legal and social problems in this world. In economics it looks like a statistical concept which is a subset of adult labor (ILO, 2015). Edmonds (2015) claims that the practice of child labor is responsible of children out of school and only option for poor families for survival. Basu et al. (2010) found that parents in poor countries have no financial capacity to send their children in school, each household is dependent on extra income on their children. In this situation the patronizing view of rich countries looks more realistic, the view assumes that parents in poor countries don't bother about the betterment of their children. The developed nations propose a punitive action against underdeveloped nations to reduce child labor practices. It is obvious that poverty is a main cause of child labor, the sanctions for poor countries brings unfavorable circumstances. Basu et al. (2010) found that only income generation activities can bring out of school 


\section{Macrothink}

children in school. They also found child labor is a luxury good for poor households in backward societies. In their framework luxury axiom postulates an upward child fertility patterns and downward education investment patterns.

Ventevogel et al. (2013) found that in poverty-stricken communities, parents demand more children for old age protection and they have low levels of opportunities to invest in their education and health. They suggested legislative amendments in system to keep these children away from work. Basu and Van (1998) framework show a good and bad equilibrium market. Basu et al. (2010) examined that adverse income effect projects poor child towards work while the adverse substitution effect ejects adult labor out of work. Basu and Van (1998) have shown that both children and adults are substitutes to each other and for poor families' children are a luxury commodity in the labor market.

Table 1. Child Labor and Parents

\begin{tabular}{ll}
\hline Effect/ Axiom & Explanation \\
\hline Substitution & The parents' choice to send their child to the school or work known as \\
effect & substitution effect. \\
& The improvement in the income level of poor households or additional \\
Income effect & income of poor parents provides an opportunity to reduce the overall \\
& stress employment of their children and help them to go to school. \\
& Parents have to send their children to the workplace only if the share of \\
Luxury axiom & adults' income drops very low.
\end{tabular}

Source: Lima et al. (2015)

The supply of child labor is a result of low family income, high cost of education (Udry, 2006). Poverty, social and economic inequality accelerate the child work as substitute of school education (Bekele and Boyden, 1988; Grootaert and Kanbur, 1995). Ab-Rahim and Tariq (2016) advocate that trade liberalization brings opportunities to invest in skills and education. Skills and education has positive effects on growth and child labor. They argue that the income effect of trade liberalization creates more options for parents to invest in education. Free trade increases relative rate of returns with positive growth in traditional economy. Trade induced child labor income effect enhance the skills in an economy and children has no incentive in the labor market due to the high marginal productivity of adult labor. 


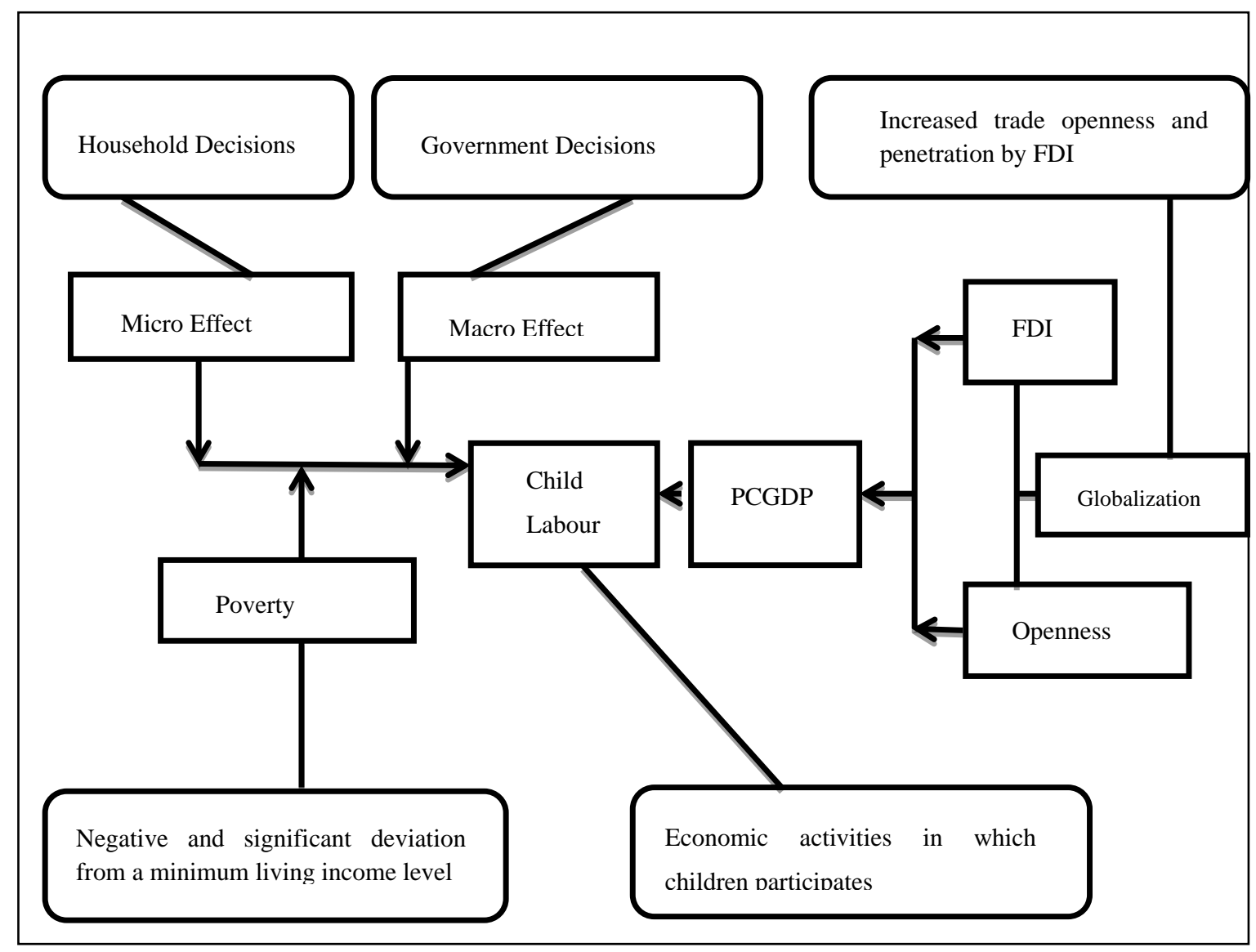

Figure 1. LaborMechanism of Child Labor in a Global World

Source: Acaroglu and Dagdemir (2010)

Edmonds and Pavcnik (2005b) found that if share of child labor is high in non-tradable sector, then there is a weak effect of trade openness on child labor. Estevez and Levy (2014) examined that child labor is merely depends on the total magnitude of income and substitution effects of household responsiveness. However, Maskus (1997) described that export sector, which involves less skills is responsible of child labor in developing countries. Sahin and Ghosh (2016) showed that expansion of conventional exportable sectors is usually the cause of child labor in undeveloped countries. Edmonds and Pavcnik (2006) supported their argument of trade and high child labor in a cross-country comparison by Stolper-Samuelson model. They proved that the supply side of child labor is highly correlated with adult wage rate. Acaroglu and Dagdemir (2010) has a similar finding for child labor supply with the help of using globalization. In their study globalization is total trade to GDP ratio. They also concluded that market regulations, government and household decisions are very import in child labor supply.

Edmonds and Pavcnik (2006) and Kaplan (2012) find that trade openness is one of the best policy options to reduce poverty, they concluded that free trade accelerate the economic growth and a major channel through which poverty and child labor can be reduced. Edmonds and Pavcnik (2006) emphasized that mobility of individuals due to trade liberalization brings 
short to medium run economic reforms, while differential impact of trade motivate the demand of adult labor in the long run. Acaroglu and Dagdemir (2010) described the various channels through which economic growth and trade openness influence the child labor. Figure 1 shows demand and supply side of child labor based on Acaroglu and Dagdemir (2010) framework. The supply side is made up by household decision to send their children to school or work, governance arrangements to provide low cost education and poverty which is the main source of child labor. The demand side of child labor is integrated with local and global economy.

\section{International Trade, Foreign Direct Investment and Child Labor}

A voluminous literature focuses on the determinants of child labor and explore the connection between international trade and the child labor. Trade literature describes the constant return to scale in production, so it is essential to involve child labor in the production process. Child labor reduces the production cost and creates competitiveness in global markets for underdeveloped countries. Kanungo (2012) claimed that trade liberalization attracts the foreign investors and increases in the demand for low cost labor in developing countries. In the production process the child labor and adult labor are close substitutes; thus demand for low cost child labor increases due to foreign investment.

Markusen et al. (1995) supports the trade liberalization to enhance the earning tendencies. They found that multinational companies encourage the potential of local workers. Foreign companies bring structural reforms in local markets. Cigno et al. (2002) examine that trade liberalization increase the influence of multinational groups in developing countries and these companies usually control the local markets of poor countries. As developing economies incorporate into the world's economy and progressively depend upon world export markets to sell their goods and services. Developed and wealthy economies can use the trade sanctions as a tool to force the policies that attempt to reduce the child labor.

Banerjee and Nag (2013) work together in two ways on child labor and trade liberalization. Firstly, trade liberalization could increase the income and employment of poor families in developing countries. Changes in national labor markets as a result of trade liberalization can reduce child labor. Secondly, trade liberalization reinforces the control of rich countries in the local policies of developing countries. Trade liberalization can increase the jobs and incomes of poor countries due to the penetration of international investments or the increase in the value of exports from developing countries.

Fluctuations and variations in channels and income opportunities in developing countries are a cause of the increased demand for child workers. Labor markets are the result of trade liberalization, sometimes increasing child labor. Moreover, children can be forced to perform many activities that are usually performed by adults (Rees et al., 2012). Willis (1973) stated that the demand for labor increases the earning opportunities of children (Serra, 2009). A developing, economy with an inefficient and disorganized workforce is likely to increase the return to unskilled labor, thereby reducing the fear of education and training. As a result, the benefits of child labor are increasing with a substitution effect, an increase in child labor and a lower school registration (Doepke and Zilibotti, 2010). 
More generally, opponents of free trade argue that trade leads countries to a race to the bottom (Singh and Zammit, 2004). More child labor could lower costs to gain a competitive advantage. Developing economies characterized by low labor standards, nominal comparisons and an abundance of unskilled labor, including child laborers, are seen as a refuge for foreign investors, a perspective called conventional wisdom (Doepke and Zilibotti, 2010).

When a country opens its borders for getting the access to the international markets, the foreign capital inflows often, but not always, come into the developing country. This is the cause of an increase in the demand for local labor and hence increase the real wage rate. In addition, nowadays some developing countries would have a competitiveness of agricultural commodities, and integration lead to higher prices for the export goods. Therefore, exportable employment rises due to liberalization, which may increase wage rates in these sectors (Davies and Voy, 2009). Trade liberalization can establish the factors that affect the child's labor supply. Social mobility and cultural influence, are more influential and traditions in developing countries, accelerate the higher acceptability of child labor (Lopez-Calva, 2002). From a political perspective, an open economy has less encouragement to secure the prominent traditional culture and institutional framework that endorses the child labor (Neumayer and De Soysa, 2005).

The effect of trade on hiring children as a labor force in poor economies, especially in agriculture, has opened an unfavorable debate. Research that reflects the analysis of real data from developing countries and mathematical models, both lead to the general conclusion that poverty is the root of all evil, not capitalism or trade liberalization (Edmonds, 2010). Poverty limits access to education, which has reduced child labor and improved the economic well-being of families. With better educational opportunities, deeper integration into a global economy and trade liberalization has empirically demonstrated a decrease in child labor volume. The cure for child labor is not very simple, but it is something that will require continuous development and the obligation to free trade and trade liberalization will be overcome. Just as developed countries have conquered their legacy of child labor through greater economic expansion, higher wages and increased training opportunities, developing countries will be able to do so in the future (Edmonds et al. Schady, 2009).

Edmonds (2010) and Ray and Chatterjee (2012) focused on the effects of child labor and the liberalization of trade in agricultural products in an environment where adolescents often work on a family farm. This is not surprising given that the highest percentage of child labor in the world is increasing in family businesses or non-market sectors. However, some argue that trade liberalization in the agricultural sector (especially in economies where a large population is dependent on independent agriculture) could lead to specific case studies because the income effects of the independent agricultural sector can play a very important role that would not be important as expressed during a trade reform.

In addition, Ab-Rahim and Tariq (2016) suggest that children who work for compensation, rather than working on their family farms, are the type of work that most interrupts education. Trade liberalization allows us to test if and how a transfer of company-wide economic 
behaviors in a country with a relatively undeveloped non-agricultural sector, and thus a huge tendency for children to wage agricultural sector, influences child labor and school preferences. Doepke and Zilibotti (2010) state that more expensive employees in the export sector increase the demand for child labor. More trade leads to an increased incidence of child labor, since they are dealing with a formal or informal sector, they provide input to the export sector.

Doepke and Zilibotti (2009) claim that trade openness does not increase the demand for child workers if children usually work in sectors that compete with imports or in the non-marketable goods segment. They suggest that the effects of trade opening would be negligible. Trade liberalization can also lead to structural changes and long-term sectoral transfer of production and capital-intensive services to highly skilled industries and services, making it less easy to recruit children. Edmonds (2015) states that openness to trade can contribute to improving the situation of child labor. One of the reasons is that openness increases import and export, resulting in an expansion of the scale of production as a whole. As a result, the level of income increases, which implies strict regulations that encourage improvement and reduce the intensity of child labor. In addition, openness to trade can accelerate the influx or diffusion of more effective techniques that help reduce the intensity of child labor. Therefore, greater openness to trade leads to a negative growth of child labor by keeping other factors constant.

Trade liberalization can delay the decision on the factors that determine the supply of child labor. Cultural and social norms are more prestigious in developing countries, which increases the social acceptability of child labor (Neumayer and De Soysa, 2005). But the level of parental awareness naturally converges to natural standards and the social acceptability of the incidence of child labor decreases due to trade liberalization. Later, they may prefer to send their children to an educational institution than to work. Trade liberalization influences the adjustment of the labor market and ethics in developing countries. The financier and the owner of the capital made their decision based on global market trends and relied less on the local offer of inexperienced and immature labor, including children (Serra, 2009). In economies where trade intensity is very low, efficient and skilled workers and owners of capital naturally benefit from maintaining the institutional culture. In addition, poor legal conditions encourage the supply of cheap, unskilled labor, including that of children (Neumayer and De Soya, 2005).

In the race to the bottom investigations in the legislation on the protection of child labor, evidence supporting the hypothesis remains mixed. The "race to the bottom" concept, based on the U-shaped "reverse" child labor curve, assumes that developing countries compete with much less stringent child labor rules to attract foreign investment from more developed countries. Developed countries are expected to relocate labor-intensive industries to prevent higher labor standards at home (Bigelow, 1997). Singh and Zammit (2004) conclude that it is unlikely that child labor policy will lead to a "race to the bottom" for both rich and poor countries in implementing child labor policy. However, the article relaxes the central assumption of immobile factors of production, which means that trade leads to illegal capital flight from developed countries that are subject to stricter rules on child labor to less developed countries. 
Table 2. A Puzzle between Race to Bottom and Inverted U Shape Hypothesis

Race to bottom

Inverted u shape

hypothesis
Governments of developing countries relax their environmental and labor standard to attract economic activity in their jurisdictions (Singh and Zammit, 2004).

Child labor would follow a reverse U-shape as it increases during the initial phase of economic growth and then decreases again with the final development phase (McBeth and Hopkins, 2009).

Singh and Zammit (2004) claim that studies that provide empirical evidence to support the reverse child labor hypothesis lend credibility to the possibility of a race to the bottom in labor policy. Many proponents of trade liberalization and workers' rights claim that trade liberalization creates a race to the bottom. These activists support the belief that free trade generates additional incentives for a competitive advantage, resulting in more child labor to reach the lowest possible labor rate. Developing countries with weak labor rules and low-skilled labor, including children, are the main target of competing companies in the global economy.

To date, Singh and Zammit (2004) are a single study that proposes a general equilibrium analysis based on traditional trade and their study hardly supports the arguments of the race to the bottom. It seems that more openness raises income levels, respect for the minimum wage and reduces child labor. The authors have developed a framework that is consistent with the international business model of Heckscher Ohlin, but there is no model or framework for monopolistic completion to investigate the effect of regulation on child labor in the workplace.

\section{Imapct of Policies and Regulations on Child Labour}

The progress against the child labor is attainable with substantial policy choices and massive commitment in the national and international level (Edmonds, 2015). Deacon et al. (2011) found that commitment to national and international level can only be possible through trade openness in SAARC countries. Ray (2000) for Pakistan, Rees et al. (2012) for India, consequently, Herath (2012), Singh and Zammit (2004), and Kaplan (2012) find that trade liberalization is one of the most common policy prescriptions offered to initiate the process of poverty and child labor eradication in today's poor countries. They agree on a single point that growth is likely the most important channel through which trade might lower poverty and child labor. These studies have emphasized the importance of short to medium run consequences of trade reforms.

Progress on child labor is a significant and substantial commitment to the national and 


\section{Mll Macrothink}

Journal of Public Administration and Governance

ISSN 2161-7104

2020, Vol. 10, No. 1

international level (Edmonds, 2015). Deacon et al. (2011) found that the creation and involvement at national and international level can only be achieved through openness of Ray (2000) for Pakistan, Rees et al. (2012) for India, Herath (2012), Singh and Zammit (2004), and Kaplan (2012) believe that trade liberalization is one of the most common rules of the current poverty reduction process. They agree on one point that growth is probably the most important channel through which trade can be a source of less poverty and child labor. These studies have emphasized the importance of short-term effects of trade reforms.

Ray (2000) uses a policy framework to investigate the effect of a stricter child labor policy on research and development in the light of high labor consumption. Doepke and Zilibotti (2005) show that the regulation of child labor in a non-cooperative context imposes high product standards on trading countries. In a subsequent study, Rogers and Swinnerton (2008) analyze the implications of a non-cooperative policy on child labor on indigenous production-external effects and conclude that international trade has uncertain effects on child labor. They investigate that in a two-sector economy, the penalty for hiring child labor directly affects profit, wages, employment, and total production in the agricultural sector. Fines reduce the chance that the child will be exploited in a company. They concluded that this reduced the number of operating companies and employment in the mining sector.

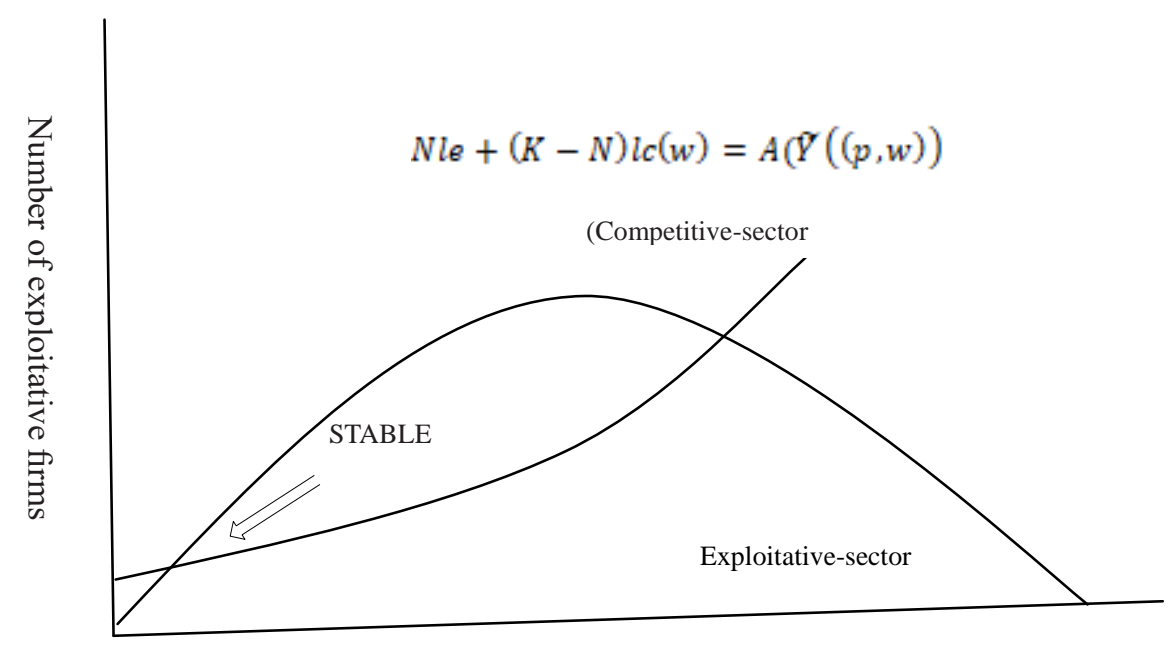

Probability of a child captured into an exploitative job

Figure 2. Multiple Two-Sector Equilibria

Source: Rogers and Swinnerton (2008)

Insight into the effects of trade policy on child labor is essential for a number of reasons. First, the accumulation of human capital is one of the most important elements of long-term growth (Iram and Fatima, 2008). A transition in parental behavior or incentives to invest in children's education can have long-term implications for growth. (Kambhampati and Rajan, 2006). Secondly, the prevalence of child labor in a certain area can have general wage effects (Rees 
et al., 2012), which in turn affect job choices and create intergenerational pitfalls of poverty (Edmonds, 2010). Persistent long-term effects can be the result of the influence of trade policy on decisions about child labor. Thirdly, empirical evidence on the relationship between child labor and trade is crucial to the debate on the application of trade sanctions to end child labor by discouraging employment opportunities for children (Edmonds and Schady, 2009).

Venture capitalists and foreign investors may be less involved in the exploitation of cheap labor, including child labor. Market stability, size and expansion, economic and political stability, infrastructure and high labor expertise are also essential for determining child labor (Hagestad and Uhlenberg, 2006). In most empirical studies, there is generally no doubt that economies characterized by lax labor standards in general and a gigantic incidence of child labor in particular attract a larger flow of FDI (Brown et al. 2012). To the extent that foreign direct investment stimulates economic development (Herath, 2012), this also has an effect on reducing the incidence of children (Brown et al., 2012). Foreign investors may also think it is more problematic to avoid anti-labor laws because they are apparently subject to a large interrogation of executors and are probably more exposed to the authorities of trade unions, consumers, human rights, media and other opposition groups (Davies and Voy, 2009).

It can be seen that the developed world is forcing governments in developing countries into child labor policies. Rich pressure from countries can be effective in reducing child labor when developing countries infiltrate the world economy (Edmonds and Turk, 2002). Governments can reduce child labor by providing scholarships to education facilitators and encouraging children to go to school instead of working. To this end, compulsory education can be used as a tool for supervisors to prevent children from working (Lopez-Calva, 2002).

Krueger (1996) found that the sharpness of child labor decreased sharply with the national income. He concluded that child labor has a negative relationship with economic development. In addition, regulators in rich economies suggest stricter labor standards and better working conditions. Regulators in emerging economies often lack the resources to enforce child labor laws. The elements of trade liberalization claim that the integration of markets, increasing labor demand, increases the income potential of young workers and therefore necessarily leads to an increase in child labor. Some opponents of trade liberalization recommend the use of trade sanctions against exporting countries to eliminate child labor (Kis-Katos and Sparrow, 2011).

Similarly, Webbink et al. (2012) investigate the effects of austere policy on research and development. They discovered how children from Asia and Africa engage in different forms of child labor. Edmonds and Pavcnik (2006) present a model of trade and child labor. The study justifies the study by Ben-Porath (1980) because it investigates the effects of trade liberalization on child labor. In a subsequent study, Edmonds (2007) examines child labor policy to take into account the external effects of local production units and concludes that the effects of child labor on trade are unclear. He expanded his previous research by linking child labor policy of modern international trade. 


\section{Macrothink \\ Journal of Public Administration and Governance \\ ISSN 2161-7104 \\ 2020, Vol. 10, No. 1}

\section{Trade and Child Labor Nexus}

The terminology of trade liberalization is generally used to describe the acceleration of the expansion of world trade and investment. It has accelerated at an exceptional pace during the recent era of globalization, making countries more interconnected (Mahmood and Azhar, 2001), and proposes two options; either by immediately adapting the development path to take advantage of the prospects of prosperity (Edmonds, 2010), or by undermining a permanent process of communicative, political, social and economic marginalization (Mahmood and Azhar, 2001). The established trend shows that the most important technology in developing countries comes from developed countries. There are relatively few case studies that show a significant breakthrough in the relationship between trade liberalization and child labor.

Krueger (1996) reported that Heckser-Olin assumes that developing countries have an abundant unskilled labor force, so these countries have relatively labor force benefits. Sign and Zammit (2004) believe that trade liberalization can not only offer relative benefits in unskilled labor-intensive sectors in developing countries, but can also lead to relative erosion of labor standards. Long-term capital transfers from developed economies to developing economies play an important role in the relative advantage. It should be noted that weak labor laws, low wages, lax labor standards and the abundant supply of unskilled labor, including working children, are considered a safe haven for foreign investors. A country can gain a comparative advantage over labor-intensive goods by making greater use of child labor by reducing labor costs. Growth as a result of increased trade openness and FDI penetration increases the labor demand and income of children (Edmonds and Pavcnik, 2006). Since the wage percentage of child labor entails economic activity, these wage problems prevent children from going to school. This relief supports the arguments of parents about sending children to work (Ranjan, 2001).

The literature on trade and child labor tells us that child labor is essential for the competitiveness of the industries of less developed countries in world trade markets. Child labor creates a competitive advantage of international trade in developing countries, while sometimes discouraging foreign direct investment (Rule, 1985). The theory of comparative advantages of international trade (Ricardo, 1817) claims that free trade enables economies to guarantee both production efficiency and resource allocation. In the Ricardian setting, children are strongly encouraged to work because of the unique production factor of work. In this context, child labor and adult work are identical in all respects. As a result, labor-intensive economies in this area are considered primarily responsible for child labor (Hanushek, 1992). 
Table 3. Traditional Trade Theory Versus New Trade Theory

\begin{tabular}{ll}
\hline Trade theory & Main features \\
\hline & The traditional trade theory has some \\
& characteristics of perfect competition with a \\
& constant return to scale; comparative \\
Traditional trade theory & advantage involves specialization in \\
& homogeneous products. \\
& The new trade theory is linked to imperfect \\
& competition with preferential economies of \\
New trade theory & scale for the specialization of varieties in \\
differentiated products.
\end{tabular}

Source: Ab-Rahim and Tariq (2016).

Traditional trade theory predicts that an increase in the price of exported goods can reduce or increase child labor, but is based on the size of income and substitution effects (Edmonds and Pavcnik, 2005). The predominantly commercial models that investigate the effects of international trade on child labor are based on traditional trade theory. Traditional trade theory states that trade in goods and services is simply determined by differences in relative factors between countries based on specialization in the production of goods for which the trading country has a comparative advantage. Traditional trade theories assume that technology provides a constant scale advantage and that markets are classified as perfect competition. With this philosophy, economies negotiate homogeneous goods and services.

The progress of the global trend of differentiated product trade suggests that the trade in differentiated products causes a sensation in international trade in goods and services. It ensures a considerable trade in differentiated products. The new trade theory shows that trade is driven by specialization and the demand for differentiated goods. The new trade theory is based on the assumption of increasing efficiency on a scale in the production process. Given these expectations, there may be trade between countries with gifting factors and indistinguishable technologies, rather than between different countries Ab-Rahim and Tariq (2017).

The recent development of Ab-Rahim and Tariq (2016) in modeling trade-labor relations of children contributes to providing theoretical foundations for empirical testing. Most analyzes are based on traditional trade theory. The work of Ranjan (2003) is based on the conventional business framework, which is based on strict assumptions of perfect competition and constant economies of scale. In contrast, the literature on the international trade in child labor in the new trade theory is relatively rare. There is a shortage of work to define the trade in differentiated products for child labor and to observe how structural changes in the business 
model affect child labor (Cigno et al., 2002). The strategic behavior of the inflow of foreign capital that influences child labor is generally investigated (Fors, 2012).

\section{Empirical Studies on Child Labor}

The generally empirical literature takes into account demand-related factors of child labor in relation to supply-side factors. Unfortunately, it is difficult in many countries to obtain data on child labor in the workplace, which can be useful for validating empirical results and even the reliability of the survey can be somewhat ambiguous, as resistance from companies to disclose information about illegal employees. Davis and Voy (2009) found empirically a weak link between trade liberalization and child labor, using instrumental variable techniques on macro-level data. One of the disadvantages of data at the macro level is the lack of data about companies that produce differentiated goods using child labor. The lack of reliable data on child labor requires a theoretical approach.

Clark (2011) examines the number of economic sectors in emerging economies, in which the expression of child labor can be traced with the help of early school leavers in primary and secondary schools. It investigates the impact of globalization on child labor using Tobit random effects models. These results are robust for a number of specifications, including first different models that are limited to longitudinal variation. The results show that international organizations have a negative effect on child labor, while foreign investments have a positive effect on child labor.

Douche et al. (2013) found that child labor can be reduced through direct foreign investment and coordination with the private sector. They perform an empirical analysis per country using data on 100 developing countries and underdeveloped countries for the period 1990-2009. This study focuses on FDI and covers only the most important economic sectors such as: finance, agriculture, mining, services. The results suggest that different economic sectors have different effects on child labor. They concluded that FDI has a significant impact on child labor in different countries and in different sectors of the economy.

The empirical assessment of Edmonds and Pavcnik (2005) found several conclusions on whether trade improves economic stability in the country, given the negative effects of child labor (Ab-Rahim and Tariq, 2016). The authors provide evidence that child labor increases, in the initial phase of economic growth, but decreases in the final phase of development (Morita and Sugawara, 2015). Davies and Voy (2009) investigated child labor in 145 countries. They found that FDI was negatively associated with child labor.

Empirical results such as Neumayer and De Soysa (2005) show that there is a negative correlation between child labor and FDI and a positive link with trade liberalization. Trade liberalization can delay the decision-making period of the factors that determine the supply of child labor. Estevez (2011) believes that comparative static results show that policies have a positive impact on reducing child labor and the well-being of unskilled labor, another contribution from his work. The results show that an increase in FDI increases the well-being of the economy and has a positive influence on the return to education and leads to a reduction in child labor. It will have a positive effect on improving the stock of human capital 
in the future and on sustainable development. This work is as good as Dinopoulos and Zhao (2007).

Bonnal (2015) uses a data panel approach to test the relationship between child labor and international trade. The results indicate that economies that trade more and have more FDI have less child labor. On the other hand, FDI appears to reduce the incidence of child labor. Noor and Abdullahi (2015) ask the impact of real gross domestic product and trade openness on child labor using the general method of moments. They show that growth has a negative impact on child labor in the initial phase, but they point out that child labor is being reduced during the final development phase.

Basu (2002) because of the substitution effect, while in Edmonds and Pavcnik (2004) the relationship is negative because of the income effect. The empirical study by Galor (2012) is based on the predictions of a formal theoretical framework and offers more convincing evidence to support the validity of the substitution effect through a short-term cost-benefit analysis.

Busse (2002) proposes a study into the relationship between trade patterns and regulation of child labor in the context of traditional trade theory. The author notes that there is statistically significant evidence in Hechsher Oilin that supports an empirical relationship between child labor regulation and trade patterns. Moreover, Kis-Katos and Sparrow (2015) found statistically significant evidence to support a relationship between trade and poverty. One of the disadvantages of the analysis is that the authors do not provide a formal framework for describing the relationship between child labor variables and trade. In short, Kis-Katos and Sparrow (2015) do not support the large scale of child labor vertically by reducing labor costs. Growth coupled with increased trade openness and FDI penetration increases the labor demand and income of children (Edmonds and Pavcnik, 2006). Using the same data, Kis-Katos and Sparrow (2011) measure the effects of trade openness in 259 Indonesian districts in the period 1993-2002 and investigate labor market mechanisms that cause poverty. The results show that this poverty has decreased, especially in districts where the tradable goods industry is more important. These findings also emphasize that the competitiveness of companies can be a key factor in reducing poverty and child labor.

Bandara et al. (2015) study of the impact of income and non-income shocks on child labor using data from national panel studies conducted in Tanzania in 2009 and 2011 in the agricultural sector. They estimate the MLS and regional impact specifications, with pooled samples from boys and girls. They discovered that agricultural productivity had significant effects on child labor and school attendance. While crop shocks have a negative effect on little girls. They conclude that the financial sector can reduce the labor of both male and female children. 
Table 4. Empirical Evidence of Child Labor

\begin{tabular}{|c|c|c|c|c|c|}
\hline Source, Year & $\begin{array}{l}\text { DATA: Country, } \\
\text { Year, Source, } \\
\text { Observations. }\end{array}$ & $\begin{array}{l}\text { Definition of } \\
\text { Child Labor }\end{array}$ & $\begin{array}{l}\text { Econometric } \\
\text { Analysis } \\
\text { Technique }\end{array}$ & $\begin{array}{l}\text { Independent } \\
\text { Variables }\end{array}$ & Findings \\
\hline Clark (2011) & $\begin{array}{l}116 \text { states with } \\
\text { total } 428 \\
\text { observations } \\
\text { Period } \\
(1980-2000)\end{array}$ & $\begin{array}{l}\text { Economically } \\
\text { Active Children, } \\
\text { Ages 10-14 }\end{array}$ & $\begin{array}{l}\text { Random Effects } \\
\text { Tobit Models of } \\
\text { Child Labor }\end{array}$ & $\begin{array}{l}\text { Primary school } \\
\text { enrollment } \\
\text { GDP PC (PPP) } \\
\text { Rural population } \\
\text { FDI inflows } \\
\text { Trade openness }\end{array}$ & $\begin{array}{l}\text { Child labor } \\
\text { decreases } \\
\text { with an } \\
\text { increase in } \\
\text { the trade } \\
\text { openness. }\end{array}$ \\
\hline $\begin{array}{l}\text { Douche et al. } \\
(2013)\end{array}$ & $\begin{array}{l}100 \text { Countries } \\
\text { Data from } 1999 \text { to } \\
2010 \text { is drawn } \\
\text { from DHS, MICS } \\
\text { and other } \\
\text { National Surveys. }\end{array}$ & $\begin{array}{l}\text { Economically } \\
\text { Active Children, } \\
\text { Ages 10-14 }\end{array}$ & $\begin{array}{l}\text { The } \\
\text { Blundell-Bond } \\
\text { system GMM } \\
\text { methodology }\end{array}$ & $\begin{array}{l}\text { GDP per capita } \\
\text { FDI/GDP } \\
\text { Control of } \\
\text { Corruption } \\
\text { Population } \\
\text { Density }\end{array}$ & $\begin{array}{l}\text { Income and } \\
\text { substitution } \\
\text { effects of FDI } \\
\text { vary across } \\
\text { the sectors } \\
\text { and regions. }\end{array}$ \\
\hline $\begin{array}{l}\text { Edmonds and } \\
\text { Pavcnik } \\
(2005)\end{array}$ & $\begin{array}{l}\text { Vietnam Living } \\
\text { Standards Survey } \\
\text { (VLSS) } \\
\text { The two rounds of } \\
\text { the VLSS } \\
1992-1993 \\
1997-1998\end{array}$ & $\begin{array}{l}\text { Labor Force } \\
\text { Participation of } \\
\text { Children Aged } \\
6-15\end{array}$ & $\begin{array}{l}\text { OLS } \\
\text { and } \\
\text { Tobit }\end{array}$ & $\begin{array}{l}\text { Rice price } \\
\text { Landholdings } \\
\text { Household fixed } \\
\text { effects } \\
\text { Season effects }\end{array}$ & $\begin{array}{l}\text { Trade } \\
\text { sanctions on } \\
\text { exports are } \\
\text { desirable to } \\
\text { eradicate } \\
\text { child labor. }\end{array}$ \\
\hline $\begin{array}{l}\text { Davies and } \\
\text { Voy (2009) }\end{array}$ & $\begin{array}{l}145 \text { countries data } \\
\text { for the year of } \\
1995 . \\
\text { The political } \\
\text { freedom index } \\
\text { comes from the } \\
\text { Freedom House } \\
\text { (2006) } \\
\text { Political rights } \\
\text { index. From the } \\
\text { CIA World } \\
\text { Factbook (2006). }\end{array}$ & $\begin{array}{l}\text { Economically } \\
\text { Active Children, } \\
\text { Ages 10-14 }\end{array}$ & $\begin{array}{l}\text { Fixed Effects to } \\
\text { the Pooled } \\
\text { Data. }\end{array}$ & $\begin{array}{l}\text { FDI } \\
\text { Income } \\
\text { Trade Openness } \\
\text { Freedom Index } \\
\text { Ratify (ILO) } \\
\text { Convention 138) } \\
\text { Freedom Index }\end{array}$ & $\begin{array}{l}\text { FDI has no } \\
\text { effect on } \\
\text { child labor }\end{array}$ \\
\hline $\begin{array}{l}\text { Neumayer } \\
\text { and De Soysa } \\
(2005)\end{array}$ & $\begin{array}{l}\text { WDI, } 2001 \\
\text { UNICEF, } 2003 \\
\text { UNCTAD, } 2003 \\
127 \text { countries } \\
\text { down to } 33 \text { at } \\
\text { maximum. }\end{array}$ & $\begin{array}{l}\text { Economically } \\
\text { Active Children, } \\
\text { Ages 10-14. }\end{array}$ & $\begin{array}{l}\text { Ordinary Least } \\
\text { Squares (OLS) }\end{array}$ & $\begin{array}{l}\text { GDP Per Capita, } \\
\text { Trade Openness. } \\
\text { Expenditure on } \\
\text { Health \%age of } \\
\text { GDP, } \\
\text { FDI Relative to } \\
\text { GDP. } \\
\text { Education }\end{array}$ & $\begin{array}{l}\text { Child labor is } \\
\text { negatively } \\
\text { correlated } \\
\text { with FDI and } \\
\text { positively } \\
\text { associated } \\
\text { with trade } \\
\text { openness. }\end{array}$ \\
\hline
\end{tabular}




\begin{tabular}{|c|c|c|c|c|c|}
\hline & & & & $\begin{array}{l}\text { Expenditure Share } \\
\text { of GDP }\end{array}$ & \\
\hline $\begin{array}{l}\text { Estevez } \\
\text { (2011) }\end{array}$ & $\begin{array}{l}118 \text { Countries } \\
\text { Data from } 1985 \text { to } \\
2007 \text { is Drawn } \\
\text { from World Bank } \\
\text { and ILO in the } \\
\text { Broadest } \\
\text { Estimation. }\end{array}$ & $\begin{array}{l}\text { Economically } \\
\text { Active Children, } \\
\text { Ages 7-14 }\end{array}$ & $\begin{array}{l}\text { Linear Least } \\
\text { Squares } \\
\text { Method }\end{array}$ & $\begin{array}{l}\text { GDP per Capita. } \\
\text { Trade Volume as a } \\
\text { Percentage of } \\
\text { GDP. } \\
\text { Value-added as a } \\
\text { Share of GDP. } \\
\text { Pupil-Teacher } \\
\text { Ratio in } \\
\text { Secondary } \\
\text { Education. }\end{array}$ & $\begin{array}{l}\text { Child labor is } \\
\text { negatively } \\
\text { correlated } \\
\text { with FDI } \\
\text { inflow, but } \\
\text { the results are } \\
\text { not } \\
\text { conclusive } \\
\text { due to } \\
\text { limitations in } \\
\text { the data. }\end{array}$ \\
\hline $\begin{array}{l}\text { Bonnal } \\
\text { (2015). }\end{array}$ & $\begin{array}{l}101 \text { countries } \\
1980 \text { to } 2004\end{array}$ & $\begin{array}{l}\text { Economically } \\
\text { Active Children, } \\
\text { Ages 10-14 }\end{array}$ & $\begin{array}{l}\text { Fixed effects } \\
\text { instrumental } \\
\text { variable } \\
\text { (FE-IV) panel } \\
\text { data mode }\end{array}$ & $\begin{array}{l}\text { Human capital } \\
\text { Technological } \\
\text { innovation } \\
\text { Credit market } \\
\text { constraints }\end{array}$ & $\begin{array}{l}\text { Trade } \\
\text { openness is } \\
\text { associated } \\
\text { with a } \\
\text { reduction of } \\
\text { child labor. }\end{array}$ \\
\hline $\begin{array}{l}\text { Noor and } \\
\text { Abdullahi } \\
(2015)\end{array}$ & $\begin{array}{l}86 \text { countries } \\
2009-2013\end{array}$ & $\begin{array}{l}\text { Labor Force } \\
\text { Participation of } \\
\text { Children Aged } \\
5-14\end{array}$ & $\begin{array}{l}\text { Generalized } \\
\text { method of } \\
\text { moments } \\
(\mathrm{GMM})\end{array}$ & $\begin{array}{l}\text { GDP } \\
\text { Trade openness } \\
\text { Population growth }\end{array}$ & $\begin{array}{l}\text { Long term } \\
\text { economic } \\
\text { growth is } \\
\text { required to } \\
\text { control the } \\
\text { child labor. }\end{array}$ \\
\hline $\begin{array}{l}\text { Iram and } \\
\text { Fatima } \\
(2008)\end{array}$ & $\begin{array}{l}\text { Annual data for } \\
\text { Pakistan from } \\
\text { 1970-2003. }\end{array}$ & $\begin{array}{l}\text { Economically } \\
\text { Active Children, } \\
\text { Ages 5-14 }\end{array}$ & $\begin{array}{l}\text { Multivariable } \\
\text { Vector auto } \\
\text { Regression } \\
\text { (VAR) model }\end{array}$ & $\begin{array}{l}\text { FDI } \\
\text { Trade Openness } \\
\text { Urbanization } \\
\text { Poverty }\end{array}$ & $\begin{array}{l}\text { Trade } \\
\text { openness } \\
\text { raises } \\
\text { demand for } \\
\text { child labor. } \\
\text { FDI } \\
\text { decreases the } \\
\text { incidence of } \\
\text { child labor }\end{array}$ \\
\hline Busse (2002). & $\begin{array}{l}83 \text { countries } \\
\text { World } \\
\text { development } \\
\text { indicators. }\end{array}$ & $\begin{array}{l}\text { Economically } \\
\text { Active Children, } \\
\text { Ages 10-14 } \\
\text { Based on Data } \\
\text { for the Year } 1998\end{array}$ & $\begin{array}{l}\text { Cross-country } \\
\text { regression } \\
\text { framework }\end{array}$ & $\begin{array}{l}\text { Total labor force } \\
\text { Female labor } \\
\text { force } \\
\text { Number of } \\
\text { ratifications }\end{array}$ & $\begin{array}{l}\text { Child labor } \\
\text { would } \\
\text { increase the } \\
\text { comparative } \\
\text { advantage in } \\
\text { unskilled } \\
\text { labor } \\
\text { intensive } \\
\text { goods. }\end{array}$ \\
\hline
\end{tabular}




\begin{tabular}{|c|c|c|c|c|c|}
\hline $\begin{array}{l}\text { Kis-Katos } \\
\text { and Sparrow } \\
(2011 ; 2015)\end{array}$ & $\begin{array}{l}259 \text { Indonesian } \\
\text { districts }\end{array}$ & $\begin{array}{l}\text { Economically } \\
\text { Active Children, } \\
\text { Ages } 10-14 \\
\text { Based on Data } \\
\text { for the Year } 1993 \\
\text { to } 2002 \text {. }\end{array}$ & $\begin{array}{l}\text { Pseudopanel } \\
\text { analysis }\end{array}$ & $\begin{array}{l}\text { Output tariffs } \\
\text { Input tariffs }\end{array}$ & $\begin{array}{l}\text { Districts } \\
\text { which have, } \\
\text { the bigger } \\
\text { industry of } \\
\text { tradable } \\
\text { goods has } \\
\text { less poverty } \\
\text { and child } \\
\text { labor. }\end{array}$ \\
\hline $\begin{array}{l}\text { Ab-Rahim } \\
\text { and Tariq } \\
(2016)\end{array}$ & $\begin{array}{l}89 \text { Developing } \\
\text { countries } \\
\text { Data from choice } \\
\text { years } 1990,2000 \\
\text { and } 2010 \\
\text { Drawn from } \\
\text { World Bank and } \\
\text { ILO and UCW }\end{array}$ & $\begin{array}{l}\text { Economically } \\
\text { Active Children, } \\
\text { Ages 5-15 in the } \\
\text { Choice years } \\
1990,2000 \text { and } \\
2010\end{array}$ & $\begin{array}{l}\text { Generalized } \\
\text { Least Squares } \\
(\mathrm{GLS})\end{array}$ & $\begin{array}{l}\text { Trade openness } \\
\text { Trade induced } \\
\text { child labor } \\
\text { selection effect } \\
\text { Trade induced } \\
\text { child labor Scale } \\
\text { effect }\end{array}$ & $\begin{array}{l}\text { Child labor } \\
\text { decreases } \\
\text { with an } \\
\text { increase in } \\
\text { the trade } \\
\text { induced child } \\
\text { labor effects }\end{array}$ \\
\hline $\begin{array}{l}\text { Bandara et al. } \\
(2015)\end{array}$ & $\begin{array}{l}\text { Tanzania National } \\
\text { panel Surveys } \\
2009(3,280 \mathrm{HHs}) \\
\text { and } 2011(3,924 \\
\mathrm{HHs})\end{array}$ & $\begin{array}{l}\text { Economically } \\
\text { Active Children, } \\
\text { Ages } 7-15\end{array}$ & $\begin{array}{l}\text { Fixed Effects to } \\
\text { the Pooled } \\
\text { Data. }\end{array}$ & $\begin{array}{l}\text { Crop Shock } \\
\text { Per Capita } \\
\text { Consumption } \\
\text { Asset Index } \\
\text { Bank Account }\end{array}$ & $\begin{array}{l}\text { Crop shocks } \\
\text { have an } \\
\text { adverse effect } \\
\text { on child } \\
\text { labor. }\end{array}$ \\
\hline Ray (2000) & $\begin{array}{l}\text { Peru Living } \\
\text { Standards } \\
\text { Measurement } \\
\text { Survey } 1994 \\
\text { (PLSS), } 3623 \\
\text { HH, 5231 } \\
\text { Children aged } \\
\text { 6-17; Pakistan } \\
\text { Integrated HH } \\
\text { Survey } 1991, \\
4800 \\
\text { HH, } 5867 \\
\text { observations on } \\
\text { children } 10 \text {-17 } \\
\text { yrs. }\end{array}$ & $\begin{array}{l}\text { Age: } \\
\text { 6-17 (Peru) } \\
\text { 10-17 (Pakistan) } \\
\text { Child labor } \\
\text { Measured as } \\
\text { Time Spent in } \\
\text { Wage } \\
\text { Labor and HH or } \\
\text { Non-Wage } \\
\text { Labor. }\end{array}$ & $\begin{array}{l}\text { Logit and } \\
\text { Probit Models }\end{array}$ & $\begin{array}{l}\mathrm{HH} \\
\text { Socioeconomic } \\
\text { Status (Poverty) } \\
\text { Adult } \\
\text { (Female } \\
\text { Education) } \\
\text { Individual } \\
\text { Characteristics } \\
\text { Child's } \\
\text { Gender/Age } \\
\text { Community } \\
\text { Characteristics }\end{array}$ & $\begin{array}{l}\text { Expenditure } \\
\text { on education } \\
\text { has a positive } \\
\text { impact on } \\
\text { school } \\
\text { enrollment } \\
\text { and negative } \\
\text { impact on } \\
\text { child labor. }\end{array}$ \\
\hline
\end{tabular}

Source: Various Studies

Kis-Katos and Sparrow (2011) present both theoretical and empirical evidence to expose the effect of child labor. The authors found evidence to support the hypothesis that the market sectors with the largest increase in child labor have the largest decrease in the net decrease in the incidence of child labor. Empirical findings based on theoretical predictions found in 
studies such as Neumayer and De Soysa (2005) and Goldberg and Pavcnik (2004) provide rather convincing evidence to validate the links of child labor in commerce.

Ab-Rahim and Tariq (2016) investigated the effects of trade-induced child labor in 89 developing countries for the selected years 1990, 2000 and 2010. They found that trade-induced effects of child labor can help to reduce child labor. The results indicate that child labor is decreasing with increasing added value in the industry. On the contrary, the trade-induced effect of child labor selection has a weak effect on children. They concluded that the link between trade and child labor could be better explained by the effects of child labor caused by trade.

Other variables (economic growth, poverty and access to educational opportunities and costs of education) are also important in these studies, but their scope does not extend to these issues. Similarly, non-economic factors, social and cultural norms, and religious beliefs are also potentially important factors in determining child labor. The major problem with these variables is that they are generally difficult to measure.

\section{Conclusion}

This article examines theoretical and empirical literature on the determinants of child labor in selected studies. Targeted studies are based on openness of trade, foreign direct investment, the impact of policies and regulations, well-being of households, socioeconomic factors of parents who determine child labor. Most studies are based on traditional trade theory. There is no formal model that explicitly shows the impact of trade in differentiated products on the quality of child labor in the context of the open economy. Theoretical and empirical analyzes of previous studies do not show the effects of increasing the strictness of child labor policy on the quality levels of local regulations in a monopolistic competition model. Our study found that there is a large number of studies that deal separately with the issue of international trade and child labor. Only a few studies are available that link the problems of both disciplines to assess their causes and consequences. There review of literature suggests that literature on the relationship between child labor and trade in the new trade theory is relatively rare. The predominantly commercial models that investigate the effects of international trade on child labor, on the other hand, are based on traditional trade theory.

\section{References}

Ab-Rahim, R., \& Tariq, B. (2016). The Effect of Trade Openness on Child Labour: Empirical Evidence from Developing Economies. International Journal of Economics and Management, 12(2), 155-171. Retrieved from http://www.ijem.upm.edu.my/vol10no1/IJEM\%20(10)\%20Rev1\%20The\%20Effect\%20of\%2 0Trade\%20Openness\%20on\%20Child\%20Labor\%20\%2019\%20June\%2016.pdf

Ab-Rahim, R., \& Tariq, B. (2017). The Impact of Trade on Child Labor: Evidence From Selected Saarc and ASEAN Countries. Journal of Indonesian Economy and Business, 32(1), 1-18. https://doi.org/10.22146/jieb.22884

Acaroglu, H., \& Dagdemir, O. (2010). The Effects of Globalization on Child Labour in 


\section{Macrothink}

Journal of Public Administration and Governance

ISSN 2161-7104

2020, Vol. 10, No. 1

Developing Countries. Business and Economic Horizons, 2, 37-47. https://doi.org/10.15208/beh.2010.15

Bandara, A., Dehejia, R., \& Lavie-Rouse, S. (2015). The impact of income and non-income shocks on child labour: evidence from a panel survey of Tanzania. World development, 67, 218-237. https://doi.org/10.1016/j.worlddev.2014.10.019

Banerjee, R., \& Nag, R. N. (2013). Globalization, Child Labour and Development Policies: A Theoretical Analysis. Foreign Trade Review, 48(1), 83-104. https://doi.org/10.1177/001573251204800104

Basu, K. (2002). A Note on Multiple General Equilibria with Child Labor. Economics Letters, 74(3), 301-308. https://doi.org/10.1016/S0165-1765(01)00567-5

Basu, K., \& Van, P. H. (1998). The Economics of Child Labour. American Economic Review, 88(3), 412-427. Retrieved from https://econpapers.repec.org/article/aeaaecrev/v_3a88_3ay_3a1998_3ai_3a3_3ap_3a412-27.h tm

Basu, K., Das, S., \& Dutta, B. (2010). Child labour and Household Wealth: Theory and Empirical Evidence of an Inverted-U. Journal of Development Economics, 91(1), 8-14. https://doi.org/10.1016/j.jdeveco.2009.01.006

Bekele, A., \& Boyden, J. (1988). Combating child labour. Geneva: International Labour Office.

Ben-Porath, Y. (1980). The F-connection: Families, Friends, and Firms and The Organization of Exchange. Population and Development Review, 6, 1-30. https://doi.org/10.2307/1972655

Bigelow, B. (1997). The Human Lives behind the Labels: The Global Sweatshop, Nike, and the Race to the Bottom. Phi Delta Kappan, 79(2), 112-119. Retrieved from https://files.eric.ed.gov/xml/index/eric1990-1999.zip

Bonnal, M. (2015). The 'amelioration 'of child labour, 'a modest proposal'. The Journal of International Trade \& Economic Development, 24(5), 616-637. https://doi.org/10.1080/09638199.2014.950685

Brown, D. K., Deardorff, A. V., \& Stern, R. M. (2012). Labour Standards and Human Rights: Implications for International Trade and Investment. IPC Working Paper Series No. 119, University of Michigan. Retrieved from https://deepblue.lib.umich.edu/bitstream/handle/2027.42/89966/ipc-119-brown-deardorff-ster n-labor-standards-human-rights-international-trade-investment.pdf? sequence $=1 \&$ isAllowed $=y$

Busse, M. (2002). Do labour standards affect comparative advantage in developing countries? World Development, 30(11), 1921-1932. https://doi.org/10.1016/S0305-750X(02)00117-1

Cigno, A., Rosati, F. C., \& Guarcello, L. (2002). Does Globalization Increase Child Labour? World Development, 30(9), 1579-1589. https://doi.org/10.1016/S0305-750X(02)00053-0 


\section{Macrothink}

Journal of Public Administration and Governance ISSN 2161-7104

Clark, R. (2011). Child Labour in the World Polity: Decline and Persistence, 1980-2000. Social Forces, 89(3), 1033-1055. https://doi.org/10.1093/sf/89.3.1033

Davies, R. B., \& Voy, A. (2009). The Effect of FDI on Child Labour. Journal of Development Economics, 88(1), 59-66. https://doi.org/10.1016/j.jdeveco.2008.02.001

Deacon, B., De Lombaerde, P., Macovei, M. C., \& Schröder, S. (2011). Globalisation and the Emerging Regional Governance of Labour Rights. International Journal of Manpower, 32(3), 334-365. https://doi.org/10.1108/01437721111136796

Dinopoulos, E., \& Zhao, L. (2007). Child Labour and Globalization. Journal of Labour Economics, 25(3), 553-579. https://doi.org/10.1086/513297

Doepke, M., \& Zilibotti, F. (2005). The Macroeconomics of Child Labour Regulation. $\begin{array}{lll}\text { American Economic Review, 1492-1524. } & \text { 95(5), }\end{array}$ https://doi.org/10.1257/000282805775014425

Doepke, M., \& Zilibotti, F. (2009). International Labour Standards and the Political Economy of Child-Labour Regulation. Journal of the European Economic Association, 7(2-3), 508-518. https://doi.org/10.1162/JEEA.2009.7.2-3.508

Doepke, M., \& Zilibotti, F. (2010). Do International Labour Standards Contribute to the Persistence of the Child-Labour Problem? Journal of Economic Growth, 15(1), 1-31. https://doi.org/10.1007/s10887-009-9048-8

Doytch, N., Thelen, N., \& Mendoza, R. U. (2014). The impact of FDI on child labor: Insights from an empirical analysis of sectoral FDI data and case studies. Children and Youth Services Review, 47, 157-167. https://doi.org/10.1016/j.childyouth.2014.09.008

Edmonds, E., \& Schady, N. (2009). "Poverty Alleviation and Child Labour". Policy Research Working Paper 4702, World Bank, Washington DC. https://doi.org/10.1596/1813-9450-4702

Edmonds, E. V. (2007). Child Labour. Handbook of Development Economics, 4, 3607-3709. Available at http://www.esocialsciences.org/Download/repecDownload.aspx?qs=Uqn/rN48N8UOPcbSX Ud2VB+JD8bwNp2xCs+VctQjwPdKKL7qp6EW2/H4Yvzki9MROhlFcwWZ2hsO7IneEdV M6h9fDy2PYrU2u3YkslD/j8WGvv4bKADOJs7asiwKKynXkSPfDVCUH2f9QLYGgC1Bn Mg5GG/LxscjogyRKIZe6cjfpvVfPtbZbILgdJjVDTQqqFxDIBZ0wgYhjFEr9JithA==

Edmonds, E. V. (2015). Economic Growth and Child Labour in Low Income Economies. Retrieved from: http:// glm-lic.iza.org/file/view/publications/2015-0814edmonds_izadraft.pdf.

Edmonds, E. V., \& Pavcnik, N. (2005). Child Labour in the Global Economy. The Journal of Economic Perspectives, 19 (1), 199-220. https://doi.org/10.1257/0895330053147895

Edmonds, E. V., \& Pavcnik, N. (2005). The Effect of Trade Liberalization on Child Labour. Journal of International 401-419. https://doi.org/10.1016/j.jinteco.2004.04.001 
Edmonds, E. V., \& Pavcnik, N. (2006). International Trade and Child Labour: Cross-Country Evidence. Journal of International Economics, 68(1), 115-140. https://doi.org/10.1016/j.jinteco.2005.01.003

Edmonds, E. V., \& Turk, C. (2002). Child Labour in Transition in Vietnam (Vol. 2774). World Bank Publications. Retrieved from http://www-wds.worldbank.org/external/default/WDSContentServer/WDSP/IB/2002/03/08/0 00094946_02022604024924/Rendered/PDF/multi0page.pdf

Edmonds, E. (2010). Trade, Child Labour, and Schooling in Poor Countries,' in G. Porto and B. Hoekman, eds., Trade Adjustment Costs in Developing Countries: Impacts, Determinants, and Policy Responses, The World Bank Press, 179-196. Retrieved from https://www.researchgate.net/profile/Beata_Javorcik/publication/237361872_New_Kids_on_t he_Block_Adjustment_of_Indigenous_Producers_to_FDI_Inflows/links/0f317532181c524eb 5000000.pdf\#page $=196$

Estevez, K. (2011). Nutritional Efficiency Wages and Child Labour. Economic Modelling, 28(4), 1793-1801. https://doi.org/10.1016/j.econmod.2011.03.004

Estevez, K., \& Levy, T. (2014). Intra-industry Trade and the Demand for Child Labour. International Journal of Economic Theory, 10(3), 275-294. https://doi.org/10.1111/ijet.12040

Ethier, W. J. (1982). National and International Returns to Scale in the Modern Theory of International Trade. The American Economic Review, 72(3), 389-405. Retrieved from https://www.jstor.org/stable/1831539?seq=1\#page_scan_tab_contents

Fors, H. C. (2012). Child Labour: A review of Recent Theory and Evidence with Policy Implications. Journal of Economic Surveys, 26(4), 570-593. https://doi.org/10.1111/j.1467-6419.2010.00663.x

Galor, O. (2012). The Demographic Transition: Causes and Consequences. Cliometrica, 6(1), 1-28. DOI: 10.1007/s11698-011-0062-7

Goldberg, P. K., \& Pavcnik, N. (2004). Trade, Inequality, and Poverty: What Do We Know? Evidence from Recent Trade Liberalization Episodes in Developing Countries. Journal of Economic Literature, 45(1), 223-269. https://doi.org/10.3386/w10593

Grootaert, C., \& Kanbur, R. (1995). Child Labour: An Economic Perspective. International Labour Review., 134(2), 187-203. Retrieved from https://heinonline.org/HOL/LandingPage?handle=hein.journals/intlr134\&div=23\&id=\&page $=$

Grubel, H. G., Lloyd, P. J., \& Lloyd, P. J. (1975). Intra-Industry Trade: The Theory and Measurement of International Trade in Differentiated Products (Vol. 12): London, Macmillan. Retrieved from https://www.academia.edu/889237/Intra-Industry_Trade_The_Theory_and_Measurement_of _International_Trade_in_Differentiated_Products

Hagestad, G. O., \& Uhlenberg, P. (2006). Should We Be Concerned about Age Segregation? 
Some Theoretical and Empirical Explorations. Research on Aging, 28(6), 638-653. http://dx.doi.org/10.1177/0164027506291872

Hanushek, E. A. (1992). The Trade-off between Child Quantity and Quality. Journal of Political Economy, 100(1), 84-117. https://doi.org/10.1086/261808

Herath, G. (2012). Child labour in Developing Countries: Review of Theoretical and Empirical Issues. Child Labour in South Asia, 11-25 Retrieved from http://books.google.com.pk/books?hl=en\&lr=\&id=IkCo4ww8q98C\&oi=fnd\&pg=PA11\&dq= Herath,+G.+(2012).+Child+labour+in+developing+countries:+review+of+theoretical+and+e mpirical+issues.+Child+labour+in+South+Asia,+11_25.\&ots=wrRHUQbhzk\&sig=Q1DwBZ nd7HfMIP6JuWF8WGGfcMQ\#v=onepage\&q\&f=false.

ILO (2015). Measuring Children's Work in South Asia. Geneva: ILO. Retrieved from https://www.ilo.org/wcmsp5/groups/public/---asia/---ro-bangkok/---sro-new_delhi/documents /publication/wcms_359371.pdf

ILO. (1993). World Labour Report 1993. Geneva: ILO. Retrieved from https://books.google.com.pk/books?id=isUWk8NtxEgC\&printsec=frontcover\&source=gbs_g e_summary_r\&cad $=0 \# \mathrm{v}=$ onepage $\& \mathrm{q} \& \mathrm{f}=$ false

Iram, U., \& Fatima, A. (2008). International Trade, Foreign Direct Investment and the Phenomenon of Child Labour: The Case of Pakistan. International Journal of Social Economics, 35(11), 809-822. https://doi.org/10.1108/03068290810905432

Kambhampati, U. S., \& Rajan, R. (2006). Economic Growth: A Panacea for Child Labour? World Development, 34(3), 426-445. https://doi.org/10.1016/j.worlddev.2005.08.010

Kanungo, A. K. (2012). FDI Inflows into South Asia: A Case Study of India's Investments in Bangladesh. Retrieved from. https://doi.org/10.2139/ssrn.2140737

Kaplan, G. (2012). Moving Back Home: Insurance Against Labour Market Risk. Journal of Political Economy, 120(3), 446-512. https://doi.org/10.1086/666588

Kis-Katos, K. (2007). Does Globalization Reduce Child Labour? The Journal of International Trade \& Economic Development, 16(1), 71-92. https://doi.org/10.1080/09638190601165558

Kis-Katos, K., \& Sparrow, R. (2011). Child Labour and Trade Liberalization in Indonesia. Journal of Human Resources, 46(4), 722-749. https://doi.org/10.1353/jhr.2011.0008

Kis-Katos, K., \& Sparrow, R. (2015). Poverty, labour markets and trade liberalization in Indonesia. Journal of Development Economics, 117, 94-106. https://doi.org/10.1016/j.jdeveco.2015.07.005

Krueger, A. B. (1996). Observations on International Labour Standards and Trade., in Proceedings of the Annual World Batik (Conference on Development Economics, 1996), Washington DC, World Bank. Retrieved from https://core.ac.uk/download/pdf/6823042.pdf

Lima, L. R., Mesquita, S., \& Wanamaker, M. (2015). Child labor and the wealth paradox: The 
role of altruistic parents. Economics Letters, 130 , 80-82. https://doi.org/10.1016/j.econlet.2015.03.005

Lopez-Calva, L. F. (2002). A Social Stigma Model of Child Labour. Estudios Economicos, 17(2), 193-217. Retrieved from http://estudioseconomicos.colmex.mx/archivo/EstudiosEconomicos2002/193-217.pdf

Mahmood, Z., \& Azhar, M. (2001). On Over Invoicing of Exports in Pakistan. The Pakistan Development Review, 40(3), 173-185. https://doi.org/10.30541/v40i3pp.173-185

Markusen, J. R., Melvin, J. R., Kaempfer, W. M., \& Maskus, K. (1995), International Trade: Theory and Evidence. New York: McGraw-Hill. Retrieved from https://ideas.repec.org/p/pra/mprapa/21989.html

Maskus, K. (1997). Should Core Labour Standards be Imposed through International Trade Policy (World Bank Development Research Group Policy Research Working Paper no. 1817), World Bank, Washington, D.C. Retrieved from http://www.worldbank.org/research/trade/wp1817.html.

McBeth, T., \& Hopkins, M. (2009). Does a Child Labour Kuznets Curve Exist? Retrieved from:

https://www.google.com/url?sa=t\&rct=j\&q=\&esrc=s\&source=web\&cd=1\&cad=rja\&uact=8 \&ved=0ahUKEwj80cfN1czNAhVFLY8KHRgWC_wQFggeMAA\&url=https $\% 3 \mathrm{~A} \% 2 \mathrm{~F} \% 2 \mathrm{Fw}$ ww.gettysburg.edu\%2FdotAsset\%2F10cf1c55-3552-49e5-af0a b5a897db1fc3.pdf\&usg=AFQjCNEfBsXwr_P3TSLDQP02SeoyJV0U1g

Morita, T., \& Sugawara, K. (2015). Human capital and FDI: Development process of the developing country in an overlapping generation model. The Journal of International Trade \& Economic Development, 24(7), 922-946. https://doi.org/10.1080/09638199.2014.986748

Neumayer, E., \& De Soysa, I. (2005). Trade Openness, Foreign Direct Investment and Child Labour. World Development, 33(1), 43-63. https://doi.org/10.1016/j.worlddev.2004.06.014

Noor, M. N., \& Abdullahi, I. (2015). The Impact of Economic Growth on Child Labour in Developing. Countries. Journal of Economics and Sustainable Development, 12(1), 206-2012.

Ranjan, P. (2001). Credit Constraints and the Phenomenon of Child Labour. Journal of Development Economics, 64(1), 81-102. https://doi.org/10.1016/S0304-3878(00)00125-5

Ranjan, P. (2003). Trade Induced Convergence through Human Capital Accumulation in a Credit-Constrained Economies. Journal of Development Economics, 72(1), 139-162. https://doi.org/10.1016/S0304-3878(03)00071-3

Ray, R. (2000). Analysis of Child Labour in Peru and Pakistan: A Comparative Study. Journal of Population Economics, 13(1), 3-19. https://doi.org/10.1007/s001480050119

Ray, R. (2000). Child labour, Child Schooling, and Their Interaction with Adult Labour: Empirical Evidence for Peru and Pakistan. The World Bank Economic Review, 14(2), 347-367. 
https://doi.org/10.1093/wber/14.2.347

Ray, R., \& Chatterjee, B. (2012). Trade and Child Labour: A Review of Theoretical Literature. Journal of International Economics, 3(1), 93-113.

Rees, R., Riezman, R., \& Marchand, B. U. (2012). The Effect of Parental Labour Supply on Child Schooling: Evidence from Trade Liberalization in India. Retrieved from http://www.ualberta.ca/ ural/files/RRUM_082012.pdf.

Ricardo, D. (1817). Principles of political economy and taxation. London: J. Murray.

Rogers, C., \& Swinnerton, K. (2008). A theory of exploitative child labour. Oxford Economic Papers, 60(1), 20-41. https://doi.org/10.1093/oep/gpm019

Rule, J. (1985). Essays in Comparative Labour History. Labour History Review, 50(1), 22-31. https://doi.org/10.3828/lhr.50.1.22

Sahin, S., \& Ghosh, A. N. (2016). Effect of Ban on Exports Containing Child Labour in a Dynamic Model in Presence of Imperfect Monitoring. Foreign Trade Review, 51(1), 26-45. https://doi.org/10.1177/0015732515615259

Serra, R. (2009). Child fostering in Africa: When Labour and Schooling Motives May Coexist. Journal of Development Economics, 88(1), 157-170. https://doi.org/10.1016/j.jdeveco.2008.01.002

Singh, A., \& Zammit, A. (2004). Labour Standards and the 'Race to the Bottom': Rethinking Globalization and Workers' Rights from Developmental and Solidarity Perspectives. Oxford Review of Economic Policy, 20(1), 85-104. https://doi.org/10.1093/oxrep/grh006

Stigler, G. J. (1957). Perfect Competition, Historically Contemplated. The Journal of Political Economy, 65(1), 1-17. https://doi.org/10.1086/257878

Tariq, B., \& Ab-Rahim, R. (2016). The Environmental Effects of Intra-Industry Trade in the SAARC Region. International Journal of Business and Society, 17(1), 113-130. https://doi.org/10.33736/ijbs.516.2016

Udry, C., (2006). Child Labour, in Banerjee, A.V., Benabou, R., and Mookherjee, D. (Eds.), Understanding Poverty. New York, Oxford University Press, 243-257.

Ventevogel, P., Jordans, M. J., Eggerman, M., van Mierlo, B., \& Panter-Brick, C. (2013). Child Mental Health, Psychosocial Well-Being and Resilience in Afghanistan: A Review and Future Directions Handbook of Resilience in Children of War (pp. 51-79): Springer. https://doi.org/10.1007/978-1-4614-6375-7_5

Webbink, E., Smits, J., \& de Jong, E. (2012). Hidden Child Labour: Determinants of Housework and Family Business Work of Children in 16 Developing Countries. World Development, 40(3), 631-642. https://doi.org/10.1016/j.worlddev.2011.07.005

Willis, R. J. (1973). A New Approach to the Economic Theory of Fertility Behaviour. The Journal of Political Economy, 81(2), 14-64. https://doi.org/10.1086/260152 


\section{Copyright Disclaimer}

Copyright for this article is retained by the author(s), with first publication rights granted to the journal.

This is an open-access article distributed under the terms and conditions of the Creative Commons Attribution license (http://creativecommons.org/licenses/by/4.0/). 